\section{Editors-in-Chief}

H.-W. Denker, Essen

A.W. English, Atlanta, Ga.

\title{
Vol. 190, 2009
}

\section{Cells Tissues
Organs}

in vivo, in vitro

Founded 1945 as 'Acta Anatomica' by R. Chambers, G. Glimstedt, T. Peterfi and G. Wolf-Heidegger

Continued $1962-1974$ by E.A. Boyden, $1955-1980$ by A. Delmas,

$1972-1980$ by F. Walberg, $1945-1980$ by G. Wolf-Heidegger,

1981-1988 by R. O’Rahilly, Davis, Calif., 1989-1990 by G.E. Goslow, Jr., Providence, R.I.,

1981-1992 by W. Lierse, Hamburg, since 1992 by H.-W. Denker, Essen, and

A.W. English, Atlanta, Ga., continued 1999 as 'Cells Tissues Organs' by H.-W. Denker, Essen, and A.W. English, Atlanta, Ga.

\section{Associate Editors}

\section{Developmental Biology}

D. Newgreen, Melbourne

E-Mail: don.newgreen@mcri.edu.au

C. Viebahn, Göttingen

E-Mail: cviebah@gwdg.de

Stem Cells and Tissue Engineering

A. Bader, Leipzig

E-Mail: augustinus.bader@bbz.uni-leipzig.de

S.F. Badylak, Pittsburgh, Pa.

E-Mail: badylaks@msx.upmc.edu

A. Müller, Würzburg

E-Mail: albrecht.müller@mail.uni-wuerzburg.de

A. Ratcliffe, San Diego, Calif.

E-Mail: anthonyratcliffe@synthasome.com

\section{A.M. Wobus, Gatersleben \\ E-Mail: wobusam@ipk-gatersleben.de}

\section{Neurosciences}

M. Frotscher, Freiburg i.Br.

E-Mail: frotsch@sun2.ruf.uni-freiburg.de

W.L. Neuhuber, Erlangen

E-Mail: winfried.neuhuber@rzmail.uni-erlangen.de

\section{Functional Anatomy and}

Biomechanics

L. Gallo, Zurich

E-Mail: luigi@zui.unizh.ch

F. Eckstein, Salzburg

E-Mail: felix.eckstein@pmu.ac.at

\section{Editorial Board}

F. Beck, Leicester

A.L. Boskey, New York, N.Y.

R.C. Burghardt, College Station, Tex.

G. Burnstock, London

F. Eckstein, Salzburg

A.C. Enders, Davis, Calif.

C. Farnum, Ithaca, N.Y.

R.H.W. Funk, Dresden

N.E. Fusenig, Heidelberg
A. Gibson, Phoenix, Ariz.

M. Glickstein, London

J.W. Hermanson, Ithaca, N.Y.

C.J. Kirkpatrick, Mainz

P. Köpf-Maier, Berlin

W. Kummer, Giessen

J.W. Lichtman, Cambridge, Mass.

K.G. Marra, Pittsburgh, Pa.

O. Ohtani, Toyama
P.J. Reier, Gainesville, Fla.

R. Roy, Los Angeles, Calif.

R. Segal, Chapel Hill, N.C.

F. Sinowatz, Munich

M. Sittinger, Berlin

T. Skutella, Tübingen

G.B. Stark, Freiburg i.Br.

E. Thompson, Melbourne

C.G. Widmer, Gainesville, Fla. 
S. Karger

Medical and Scientific Publishers

Basel $\cdot$ Freiburg $\cdot$ Paris $\bullet$ London •

New York $•$ Bangalore $\cdot$ Bangkok

Shanghai $\cdot$ Singapore $\cdot$ Tokyo $\cdot$ Sydney
Disclaimer

The statements, opinions and data contained in this publication are solely those of the individual authors and contributors and not of the publisher and the editor(s). The appearance of advertisements in the journal is not a warranty, endorsement or approval of the products or services advertised or of thei effectiveness, quality or safety. The publisher and the editor(s) disclaim responsibility for any injury to persons or property resulting from any ideas, methods, instructions or products referred to in the content or advertisements.

Drug Dosage

The authors and the publisher have exerted every effort to ensure that drug selection and dosage set forth in this text are in accord with current recommendations and practice at the time of publication. However, in view of ongoing research, changes in government regulations, and the constant flow of information relating to drug therapy and drug reactions, the reader is urged to check the package insert for each drug for any change in indications and dosage and for added warnings and precautions. This is particularly important when the recommended agent is a new and/or infrequently employed drug.
All rights reserved.

No part of this publication may be translated into other languages, reproduced or utilized in any form or by any means, electronic or mechanical, including photocopying, recording, microcopying, or by any information storage and retrieval system, without permission in writing from the publisher or, in the case of photocopying, direct payment of a specified fee to the Copyright Clearance Center (see 'General Information')

(c) Copyright 2009 by S. Karger AG,

P.O. Box, CH-4009 Basel (Switzerland)

Printed in Switzerland

on acid-free and non-aging paper (ISO 9706) by

Reinhardt Druck, Basel

\section{KARGER}


No. 1

Original Papers

1 Is Continuous Treatment with Transforming Growth Factor-Beta Necessary to Induce Chondrogenic Differentiation in Mesenchymal Stem Cells?

Kim, H.-J.; Kim, Y.-J.; Im, G.-I. (Goyang)

11 Lithium Chloride Preconditioning Optimizes Skeletal Myoblast Functions for Cellular Cardiomyoplasty in vitro via Glycogen Synthase Kinase-3 $\beta / \beta$-Catenin Signaling Du, W.J.; Li, J.K.; Wang, Q.Y.; Hou, J.B.; Yu, B. (Harbin)

20 Effect of Insulin-Like Growth Factor-I Gene Therapy on the Somatotropic Axis in Experimental Prolactinomas Cónsole, G.M.; Hereñú, C.B.; Camihort, G.A.; Luna, G.C.; Ferese, C.; Goya, R.G. (La Plata)

27 Organ-Specific Changes in the Expression of Mannose-6Phosphate Receptors during Postnatal Development in Rats Jofré, G.F.; Balmaceda, V.; Sartor, T.; Carvelli, L.; Barrera, P.; Sosa, M.A. (Mendoza)

34 Immunohistochemical Comparison of Markers for Wound Healing on Plastic-Embedded and Frozen Mucosal Tissue Mai, R. (Dresden); Gedrange, T. (Greifswald); Leonhardt, H..; Sievers, N.; Lauer, G. (Dresden)

42 Postnatal Development of Fiber Type Composition in Rabbit Jaw and Leg Muscles

Korfage, J.A.M.; Helmers, R.; de Goüyon Matignon, M.; van Wessel, T.; Langenbach, G.E.J.; van Eijden, T.M.G.J. (Amsterdam)

53 The Bovine Kidney as an Experimental Model in Urology: External Gross Anatomy

Carvalho, F.S.; Bagetti Filho, H.J.S. (Teresopólis); Henry, R.W.

(Knoxville, Tenn.); Pereira-Sampaio, M.A. (Niterói)

59 Patent Watch

60 Conference Calendar

No. 2

Original Papers

61 Effect of Mechanical Stimulation on Osteoblast- and Osteoclast-Like Cells in vitro

Kadow-Romacker, A.; Hoffmann, J.E.; Duda, G.; Wildemann, B.; Schmidmaier, G. (Berlin)

69 Regulation of Osteoblast Differentiation by Slit2 in Osteoblastic Cells

Sun, H.; Dai, K.; Tang, T.; Zhang, X. (Shanghai)

81 Low Oxygen Expansion Improves Subsequent Chondrogenesis of Ovine Bone-Marrow-Derived Mesenchymal Stem Cells in Collagen Type I Hydrogel Zscharnack, M.; Poesel, C.; Galle, J.; Bader, A. (Leipzig)
94 Application of Autologous Cryopreserved Bone Marrow Mesenchymal Stem Cells for Periodontal Regeneration in Dogs

Li, H. (Fuzhou/Zunyi); Yan, F.; Lei, L.; Li, Y. (Fuzhou); Xiao, Y. (Brisbane, Qld.)

102 Evaluation of Animal Models for the Hair-Inducing Capacity of Cultured Human Dermal Papilla Cells

Inoue, K.; Kato, H. (Tokyo); Sato, T.; Osada, A. (Yokohama); Aoi, N Suga, H.; Eto, H.; Gonda, K.; Yoshimura, K. (Tokyo)

111 An Analytical Model for Elucidating Tendon Tissue Structure and Biomechanical Function from in vivo Cellular Confocal Microscopy Images

Snedeker, J.G. (Balgrist/Zürich); Pelled, G.; Zilberman, Y.; Ben Arav, A. (Jerusalem); Huber, E.; Müller, R. (Zürich); Gazit, D. (Jerusalem/ Los Angeles, Calif.)

120 Conference Calendar

No. 3

Original Papers

121 Histone Deacetylase Inhibitor, Trichostatin A, Affects Gene Expression Patterns during Morphogenesis of Chicken Limb Buds in vivo

Zhao, W. (Lanzhou/Freiburg); Dai, F.; Bonafede, A.; Schäfer, S.; Jung, M.; Yusuf, F.; Gamel, A.J. (Freiburg); Wang, J. (Lanzhou); Brand-Saberi, B. (Freiburg)

135 In vitro Differentiation of Human Cord Blood-Derived Unrestricted Somatic Stem Cells into Hepatocyte-Like Cells on Poly( $\varepsilon$-Caprolactone) Nanofiber Scaffolds

Hashemi, S.M.; Soleimani, M.; Zargarian, S.S.; Haddadi-Asl, V.; Ahmadbeigi, N.; Soudi, S.; Gheisari, Y.; Hajarizadeh, A.; Mohammadi, Y. (Tehran)

150 Osteogenic and Adipogenic Cell Fractions Isolated from Postnatal Mouse Calvaria Steenhuis, P.; Carr, K.M.; Pettway, G.J.; Ignelzi, M.A., Jr. (Ann Arbor, Mich.)

158 Differential FGF Ligands and FGF Receptors Expression Pattern in Frontal and Parietal Calvarial Bones Quarto, N. (Stanford, Calif./Napoli); Behr, B.; Li, S.; Longaker, M.T. (Stanford, Calif.)

170 New Components of 'Basal Laminar Deposits' in Age-Related Macular Degeneration

Reale, E.; Groos, S. (Hannover); Eckardt, U.; Eckardt, C. (Frankfurt); Luciano, L. (Hannover)

182 Patent Watch

184 Conference Calendar

\section{KARGER}

Fax +41613061234 E-Mail karger@karger.ch www.karger.com

\section{(2009 S. Karger AG, Basel}

Access to full text and tables of contents, including tentative ones for forthcoming issues: www.karger.com/cto_issues 


\section{No. 4}

Original Papers

185 Induced Endothelial Cells Enhance Osteogenesis and Vascularization of Mesenchymal Stem Cells Tao, J.; Sun, Y.; Wang, Q.; Liu, C. (Shanghai)

194 Isolation, Culture and Characterization of Cardiac Progenitor Cells Derived from Human Embryonic Heart Tubes

Zhang, X.; Zhang, C.-S.; Liu, Y.-C.; Yang, X.-Q.; Xiong, S.-H.; Wen, Y.; Jiang, E.-P.; Li, R.; Zhang, Z.-Y.; Liu, F.; Ye, Y. (Shanghai)

209 Cartilage Collagen Fibril Network in Newborn Transgenic Mice Analyzed by Electron Microscopic Stereology

Långsjö, T.K. (Kuopio/Vaasa); Arita, M. (Philadelphia, Pa.); Helminen, H.J. (Kuopio)

219 Pituitary Pars Intermedia of Male Viscacha (Lagostomus maximus maximus): A Morphometric Study of Seasonal and Age-Related Changes in Immunohistochemistry Acosta, M.; Mohamed, F. (San Luis)

230 Ultrastructural Observations on the Progress of Nerve Degeneration and Regeneration at the Suture Site following Vagal-Hypoglossal Nerve Coaptation in Cats Hu, M.-E; Tyan, Y.-S. (Taichung); Hsu, P.-W.; Hsu, J.-C. (Taipei); Chang, H.-M. (Taichung); Ling, E.-A. (Singapore); Lan, C.-T. (Taichung)

246 Conference Calendar

No. 5

Original Papers

247 Function-Orientated Structural Analysis of the Proximal Human Femur

Skuban, T.P. (Munich); Vogel, T. (Bochum); Baur-Melnyk, A.; Jansson, V.; Heimkes, B. (Munich)

256 Efferent Projections of the Anterior and Posterodorsal Regions of the Medial Nucleus of the Amygdala in the Mouse Usunoff, K.G. (Sofia/Rostock); Schmitt, O. (Rostock); Itzev, D.E. (Sofia); Haas, S.J.-P. (Rostock); Lazarov, N.E. (Sofia); Rolfs, A.; Wree, A. (Rostock)
286 Development of the Human Retroperitoneal Fasciae Matsubara, A. (Hiroshima); Murakami, G. (Iwamizawa); Niikura, H. (Sendai); Kinugasa, Y. (Nagaizumi); Fujimiya, M. (Sapporo); Usui, T. (Hiroshima)

297 Anatomy of the Ligamentum Venosum Arantii and Its Contribution to the Left Hepatic Vein and Common Trunk Control. A Study on Cadaveric Livers

Dahmane, R. (Ljubljana); Morjane, A. (Monastir); Ravnik, D.; Hribernik, M. (Ljubljana)

301 Patent Watch

302 Conference Calendar

No. 6

Original Papers

303 Development of Tissue-Engineered Human Periodontal Ligament Constructs with Intrinsic Angiogenic Potential Nagai, N.; Hirakawa, A.; Otani, N.; Munekata, M. (Sapporo)

313 Genipin Cross-Linked Fibrin Hydrogels for in vitro Human Articular Cartilage Tissue-Engineered Regeneration

Dare, E.V.; Griffith, M.; Poitras, P. (Ottawa, Ont.); Kaupp, J.A.; Waldman, S.D. (Kingston, Ont.); Carlsson, D.J.; Dervin, G.; Mayoux, C.; Hincke, M.T. (Ottawa, Ont.)

326 Regeneration of Central Nervous Tissue Using a Collagen Scaffold and Adipose-Derived Stromal Cells

Nakada, A.; Fukuda, S.; Ichihara, S.; Sato, T.; Itoi, S.; Inada, Y.; Endo, K.; Nakamura, T. (Kyoto)

336 Ex vivo Model of Cranial Suture Morphogenesis and Fate Slater, B.J.; Lenton, K.A.; James, A.; Longaker, M.T. (Stanford, Calif.)

347 Regeneration of a Spinal Ligament after Total Lumbar Disk Arthroplasty in Primates

Cunningham, B.W. (Baltimore, Md.); Berven, S.H. (San Francisco, Calif.); Hu, N.; Beatson, H.J. (Baltimore, Md.); De Deyne, P.G. (Raynham, Mass.); McAfee, P.C. (Baltimore, Md.)

356 Conference Calendar

357 Acknowledgement to Reviewers

359 Author Index Vol. 190, 2009

361 Subject Index Vol. 190, 2009 